УДК 551.21

\title{
О НЕКОТОРЫХ ОСОБЕННОСТЯХ ИЗВЕРЖЕНИЯ ВУЛКАНА МОЛОДОЙ ШИВЕЛУЧ, КАМЧАТКА, 22 СЕНТЯБРЯ 2005 Г.
}

\author{
(C) 2014 г. О. А. Гирина, А. А. Нуждаев \\ Институт вулканологии и сейсмологии ДВО РАН \\ 683006 Петропавловск-Камчатский, б-р Пийпа, 9, \\ e-mail: girina@kscnet.ru \\ Поступила в редакцию 17.06.2013 г.
}

\begin{abstract}
22 сентября 2005 г. произошло эксплозивное извержение вулкана Молодой Шивелуч, в результате которого в долине р. Байдарная был сформирован пирокластический поток длиной около 20 км, в районе Северной группы вулканов прошел пеплопад.
\end{abstract}

DOI: $10.7868 / \mathrm{S} 0203030614040038$

Молодой Шивелуч - один из наиболее активных вулканов Камчатки. Спустя почти 16 лет после катастрофического извержения, произошедшего 12 ноября 1964 г., в эксплозивном кратере вулкана с осени 1980 г. начал расти новый экструзивный купол, рост которого продолжается и поныне [Мелекесцев и др., 1991; Гирина и др., 2006]. Характер извержения с течением времени менялся: с 1984 г. в районе лавового купола начали происходить отдельные мощные эксплозии [Федотов и др., 1985]; с 2001 г. - выжиматься вязкие лавовые потоки [Гирина, 2008; Girina et al., 2002]; но процесс выноса магматического вещества на поверхность земли в районе вулкана Молодой Шивелуч был почти непрерывным [Двигало, 1984; Жаринов и др., 1995; Гирина и др., 2007б; и др.]. Под непрерывностью выноса магматического вещества на поверхность земли в районе этого вулкана авторы подразумевают и поступление свежей лавы на склоны лавового купола, и вынос магматического газа, которые обусловливают почти непрерывную регистрацию на спутниковых снимках термальной аномалии в районе вулкана Молодой Шивелуч (http://www.kscnet.ru/ivs/kvert). Сильные пароксизмальные эксплозивные фазы извержения, связанные с ростом лавового купола, наблюдались до описываемого события в 1993, 2001, 2004, в феврале 2005 гг. [Хубуная и др., 1995; Федотов и др., 2001; Гирина и др., 2006; Гирина и др., 2007а; Гирина и др., 2007б].

27 февраля 2005 г. произошло самое сильное эксплозивное извержение вулкана с 1964 г. с объемом изверженных продуктов около $0.5 \mathrm{kм}^{3}$ [Гирина и др., 2006; Гирина и др., 2007а]. Отложения тефры и пирокластических потоков заняли площади около $25000 \mathrm{KM}^{2}$ и $31.5 \mathrm{KM}^{2}$ соответственно [Гирина и др., 2006].
Сразу после февральского извержения на вулкане Молодой Шивелуч началось интенсивное выжимание нового лавового вещества. По данным Н.В. Горбач [2006], расход лавы в течение двух месяцев (март-апрель) составил $4.5-5 \mathrm{~m}^{3} / \mathrm{c}$.

\section{ПОДГОТОВКА ИЗВЕРЖЕНИЯ}

Сейсмическая информация, предшествовавшая эксплозивному извержению 22 сентября, не полная, в связи с тем, что сейсмостанция Камчатского филиала Геофизической службы (КФ ГС) РАН, находившаяся в 8 км от вулкана, была разрушена при февральском извержении [Гирина и др., 2006; Сенюков и др., 2006]. В марте-августе 2005 г. мониторинг вулкана проводился с использованием данных удаленных сейсмостанций, поэтому отмечались лишь отдельные относительно сильные сейсмические события с магнитудой до 2.2 , но в середине августа был зарегистрирован рой вулканических землетрясений (13-16 августа в районе вулкана в сутки фиксировалось по 7-14 землетрясений с магнитудой 1.5-2.2 на глубине до 2.5 км), указывавший на усиление активности вулкана [Сенюков и др., 2006].

По визуальным данным, в марте-июне вулкан был очень активен - наблюдался интенсивный рост лавового купола (лава выжималась в виде экструзивных блоков и коротких лавовых потоков), сопровождавшийся редкими эксплозивными событиями и раскаленными лавинами, при обрушении которых на склон купола пепел поднимался до 3-5 км над уровнем моря (н.у.м.) [Гирина и др., 2007а]. Первый пепловый выброс до 4 км н.у.м. со времени февральского эксплозивного извержения вулкана произошел 1 июня [Гирина и др., 2007а]. По нашим наблюдениям из района р. Байдарная, 29 июня-10 июля почти постоянно происходили обрушения блоков расту- 


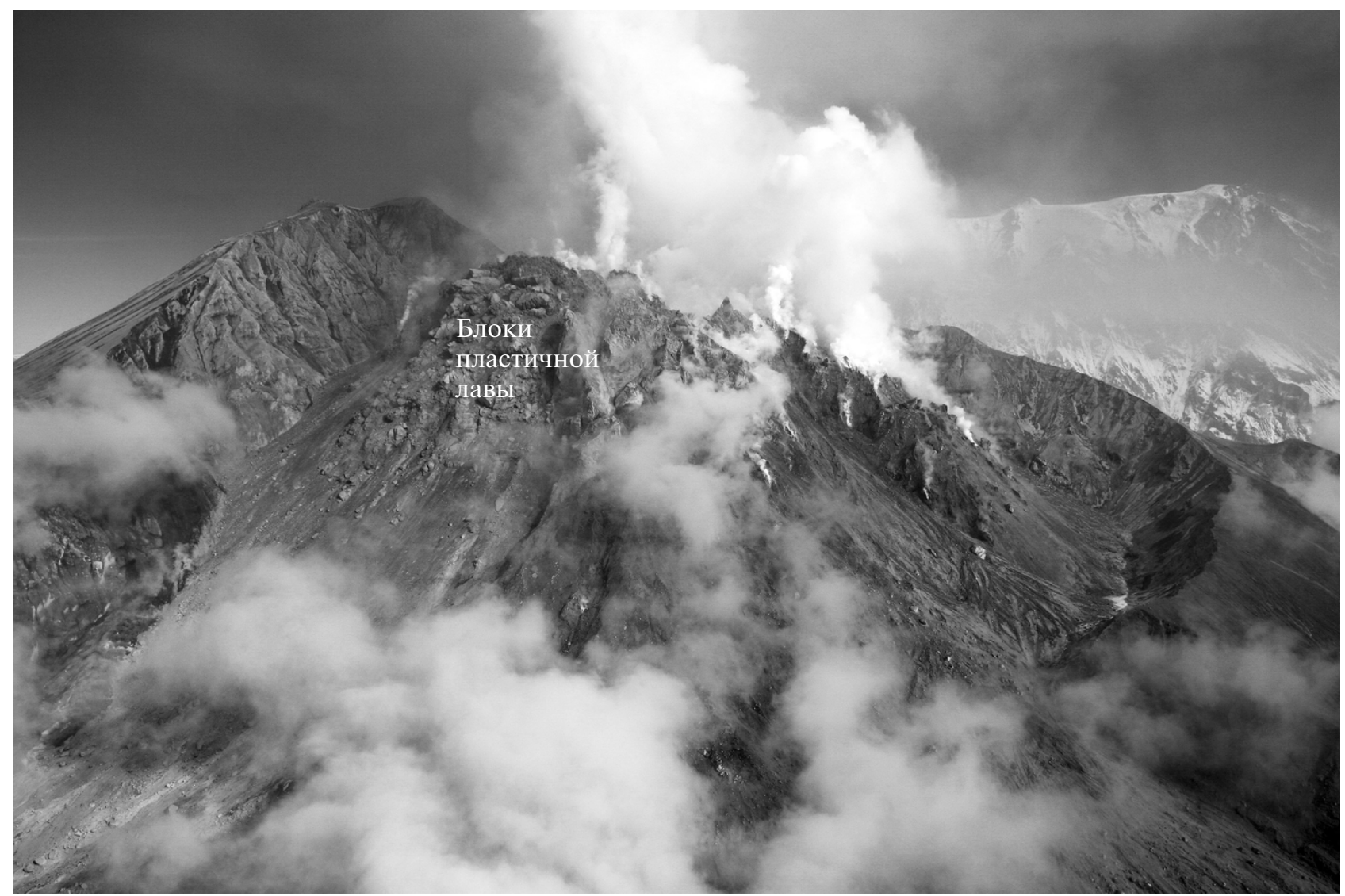

Рис. 1. Пластичная лава на юго-западном склоне вулкана Молодой Шивелуч. Фото от 14.09.2005 Ю. Демянчука.

щего купола и формирование раскаленных лавин: 30 июня с 17:25 до 18:15 UTC непрерывно обрушивались раскаленные лавины с подъемом пепловых облаков до 5 км н.у.м. и распространением пепловых шлейфов на запад-юго-запад от вулкана; 4-5 июля пепел от раскаленных лавин также поднимался до 5 км н.у.м., шлейфы протягивались на северо-запад и запад от вулкана; 6 июля в 01:07 и в 21:39 UTC эксплозии поднимали пепел до 7.5 и 6 км н.у.м. соответственно, пепловые шлейфы распространялись на северо-запад от вулкана. Отложения самой крупной из раскаленных лавин 10 июля протянулись по юго-западному подножию купола на 4.5 км [Гирина и др., 2007а].

19 августа впервые было отмечено нависание фронтальной части одного из лавовых потоков над юго-западной частью купола. Более частыми стали раскаленные лавины, срывавшиеся с фронтальных частей потока, например, 19-21 и 28 августа в темное время суток наблюдалось свечение этого потока и раскаленных лавин. 28 августа были отмечены две, 29 августа - три крупные лавины с купола, пепловые шлейфы от которых поднимались до 5.5 км н.у.м. По спутниковым данным Аляскинской вулканологической обсерватории (ABO), США (http://www.avo.alaska.edu/) и Камчат- ской группы реагирования на вулканические извержения (KVERT - Kamchatkan Volcanic Eruption Response Team) (http://www.kscnet.ru/ivs/kvert/), в районе купола вулкана непрерывно фиксировалась термальная аномалия размером до 9 пикселов, после обрушения раскаленных лавин отмечались пепловые шлейфы, которые протягивались до 40 км в восточных направлениях от вулкана.

Благодаря новой сейсмостанции “Семкорок” КФ ГС РАН, начавшей работать 11 сентября 2005 г. на восточном склоне вулкана Шивелуч в 15 км от лавового купола, картина сейсмичности вулкана несколько детализировалась: 11-21 сентября было отмечено 28 поверхностных землетрясений с магнитудой 1.7-2.8, с 13 до 21 сентября регистрировалось вулканическое дрожание величиной до 0.24 мкм/c (http://emsd.iks.ru/ ssl/monitoring/main.htm). По видео и визуальным данным, выжимание блоков пластичной лавы на вершине западной части купола продолжалось (рис. 1). 13 сентября отмечалось свечение этого сектора лавового купола, почти ежедневно здесь наблюдалось обрушение раскаленных лавин. По спутниковым данным, до 16 сентября в районе купола фиксировалась крупная термальная аномалия, 16-24 сентября вулкан был закрыт плотными облаками. 


\section{ЭКСПЛОЗИВНОЕ ИЗВЕРЖЕНИЕ}

Пароксизмальное эксплозивное извержение вулкана, связанное с ростом лавового купола, произошло 22 сентября и продолжалось с 07:38 до 16:00 UTC (по сейсмическим данным КФ ГС РАН [Сенюков и др., 2006]). Вулканическое дрожание величиной 4.46 мкм/с регистрировалось в течение 8.6 ч, кроме этого, были зафиксированы вулканические землетрясения с магнитудой до 2.9: 11 с глубины до 11 км и 37 поверхностных (http://emsd.iks.ru/ ssl/monitoring/main.htm). По спутниковым данным, пепловая колонна поднялась до 7.5 км н.у.м., пепловый шлейф протянулся на 480 км на юго-восток от вулкана [Гирина и др., 2007a]. По визуальным данным сейсмологов КФ ГС РАН, которые работали на юго-западном гребне вулкана над долиной р. Байдарная (примерно в 910 км от лавового купола), с 06:00 до 08:00 UTC 22 сентября в их лагере отмечался пеплопад, мощность пепла составила около 2-3 см. По сообщению Ю.В. Демянчука, ось основного пеплового шлейфа прошла немного западнее р. Хапица; на склоне Ключевского вулкана, в 60 км от вулкана Шивелуч, мощность пепла была около 0.30.5 см, его количество составило около 200 г/м ${ }^{2}$ [Гирина и др., 2007a].

\section{ПРОДУКТЫ ИЗВЕРЖЕНИЯ}

Полевые исследования изверженных продуктов были проведены авторами 4-5 октября 2005 г. Отложения пирокластического потока узкой полосой протянулись по долине р. Байдарная на 20 км, средняя мощность отложений не превысила 4-5 м, общий объем продуктов - $0.01 \mathrm{kM}^{3}$ [Нуждаев и др., 2005]. Поверхность потока была относительно ровной, так как количество заполнителя потока (частицы размером <2 мм) значительно преобладало над количеством обломков в нем. Такие потоки называют пирокластическими потоками пористых андезитов [Богоявленская, Брайцева, 1988; Гирина, 1998]. Доминировали обломки лавы размером до 30-40 см, но встречались отдельные глыбы (длиной до 4 м) и их нагромождения. Поток заполнил новое русло р. Байдарная, которое образовалось в отложениях февральского пирокластического потока в течение 6 мес. в результате уплотнения отложений и размыва их ручьями. В верховьях реки отложения потока полностью заполнили ее русло (рис. 2a), в средней части, там, где врез новообразованной долины в пирокластических отложениях февральского извержения 2005 г. был наибольшим (до 7-8 м), - лишь частично (см. рис. 2б), фронтальные части потока лежали на выположенной равнине, сложенной образованиями февральского извержения. Мощность отложений на фронте потока не превышала 2-2.5 м, в заплесках на склонах долины - 1.5 м. На свежих сентябрьских пирокластических отложениях в средней части долины р. Байдарная наблюдались многочисленные фумаролы. Спустя 12 дней после извержения отложения пирокластического потока были высокогазонасыщенны, вулканологи проваливались в них по колено и выше, плотность естественного сложения верхней части пирокластики, по данным авторов, варьировалась в пределах $1.33-1.71$ г $/ \mathrm{cm}^{3}$ (14 образцов), в среднем составля-

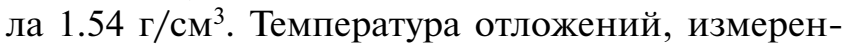
ная с помощью термопары, на глубине 15-20 см достигала $165^{\circ} \mathrm{C}, 130 \mathrm{~cm}-378^{\circ} \mathrm{C}$. Максимальная температура отложений (наиболее газонасыщенных с наименьшей плотностью сложения) $430^{\circ} \mathrm{C}$ и $512^{\circ} \mathrm{C}$ была замерена на глубинах 38 и 47 см соответственно (рис. 3a). В 5 км от лавового купола в средней части пирокластического потока возле навала крупных глыб было обнаружено фонтанирование сухого песка. Температура песка на глубине 40 см была $332^{\circ} \mathrm{C}$ (см. рис. 3б). Вулканологами не раз отмечалось, что в местах навалов крупных горячих глыб, захороненных под слоем средне-крупнозернистой пирокластики, часто формируются “бескорневые фумаролы" [Макдональд, 1975]. Газы таких фумарол образуются в основном в результате взаимосвязанных процессов дегазации пирокластики при остывании и вскипания метеорных вод в толще пирокластики [Ceрафимова, 1992]. Вероятно, фонтанирование песка было обусловлено мощным потоком смеси газа, выделяющегося при дегазации глыб, и водяного пара, т.к. металлическая пластина, внесенная в фонтан песка, становилась влажной.

Кроме отложений пирокластического потока, авторами был изучен пепел, отобранный сейсмологами 22 сентября на юго-западном гребне вулкана над долиной р. Байдарная в 9-10 км от лавового купола. Вероятно, этот пепел отложился из пеплового облака, поднявшегося над пирокластическим потоком, то есть пепел представлял собой “отложения пепловых облаков пирокластического потока”, или коротко “пепел облаков потока” [Гирина, 1998].

\section{СОСТАВ ПОРОД}

Породы Шивелуча в основном относятся к умеренно-калиевой известково-щелочной серии, но отличаются от других пород Камчатки этой серии повышенным содержанием магния и никеля и повышенными значениями отношений магния к железу и никеля к кобальту; также в породах отмечается повышенное содержание мафических минералов во вкрапленниках [Рудич и др., 1974; Пополитов, Волынец, 1981]. По данным Н.В. Горбач [2006], содержание кремнекислоты в свежих обломках лавы дациандезита, отобранных из пирокластического потока, изверженного 22 сен- 

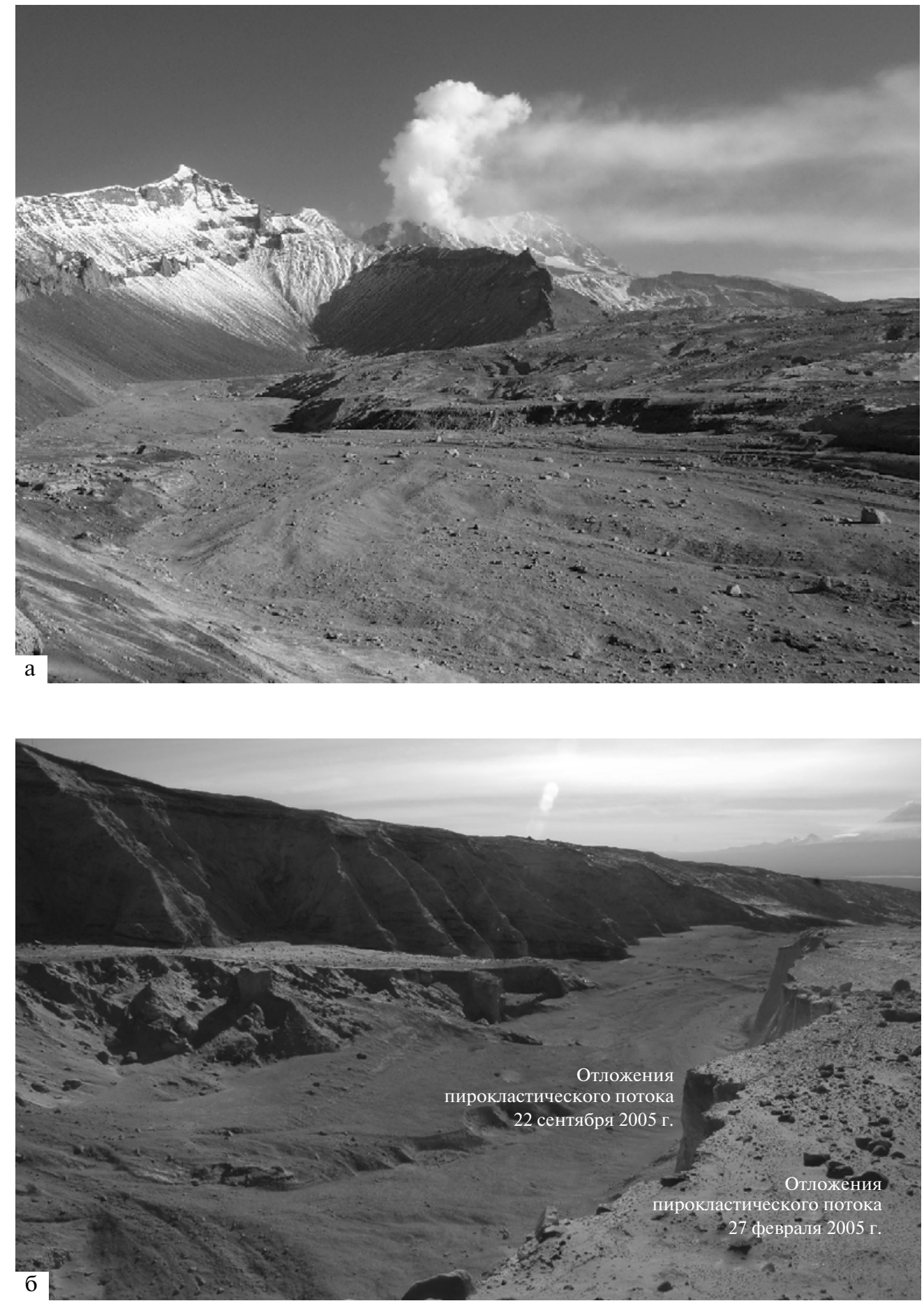

Рис. 2. Отложения пирокластического потока, извергнутого 22 сентября 2005 г., в долине р. Байдарная: в ее верховьях (а), фото от 05.10.2005 А. Нуждаева; в ее средней части (б), фото от 05.10.2005 В. Шушлина.

тября, варьируется от 63.5 до 63.9 мас. \%. Состав вкрапленников типичен для лав Молодого Шивелуча: плагиоклаз, пироксен, амфибол, магнетит, изредка встречается биотит. Особенностью лав было наличие роговой обманки двух видов: чистых идиоморфных кристаллов и зерен с тонкой опацитовой каймой [Горбач, 2006].
В связи с тем, что изверженные продукты изучались спустя 12 дней после эксплозивной фазы, пирокластические отложения обладали большой газонасыщенностью и высокой температурой. Отложения пирокластических волн, которые, естественно, присутствовали при этом извержении, было достаточно сложно отделить от пиро- 

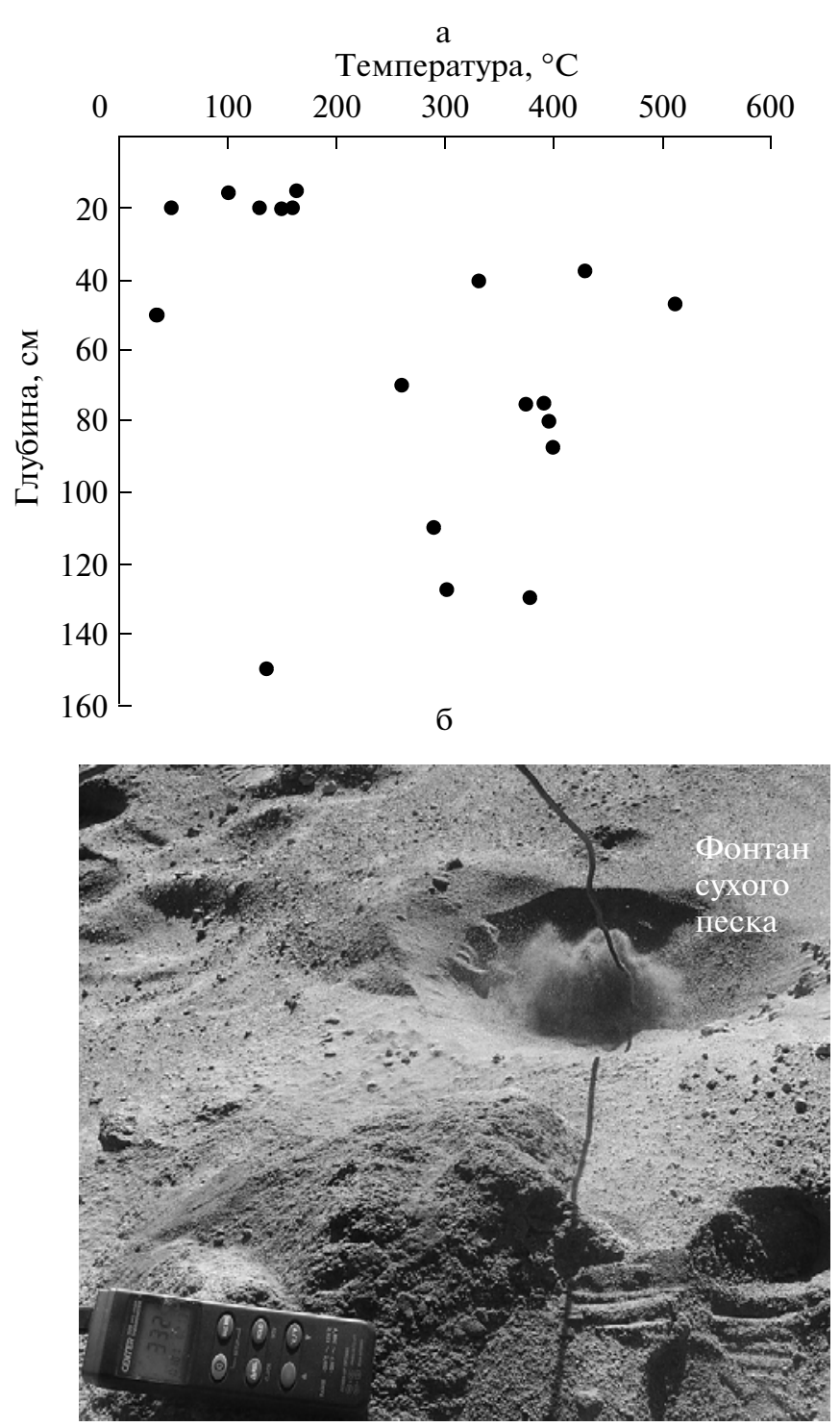

Рис. 3. Температура отложений пирокластического потока, извергнутого 22 сентября 2005 г., измеренная 4-5 октября 2005 г. (а); фонтанирование сухого песка: температура измерена на глубине 40 см (б), фото от 05.10.2005 А. Нуждаева.

кластических потоков, поэтому пирокластические отложения рассматривались авторами как нерасчлененные образования пирокластических потоков.

По гранулометрическому составу заполнители (частицы размером менее 2 мм) отложений пирокластических потоков относятся к пескам средней крупности и мелким; пепел облаков потоков - к пескам пылеватым. В составе пепла облаков потоков преобладают частицы размером <0.056 мм (77\%) (рис. 4a). Отложения их однородные, нестратифицированные, с массивной текстурой. Среди заполнителей пирокластических потоков два образца (2 и 3) выделяются преобладанием в их составе тонкозернистых и мелких фракций (частиц размером $<0.056$ мм в них содержится $22 \%$, размером 0.125-0.25 мм - 19-20\%) в отличие от других образцов, в которых преобладает крупнозернистая фракция 0.5-1.0 мм (24-25\%), но тонкая фракция $(<0.056)$ в среднем составляет $15-17 \%$ и лишь в одном случае $-20 \%$ (см. рис. $4 a)$. Кумулятивные кривые заполнителей потоков образцов 2 и 3 при сходном угле наклона залегают выше поля кривых остальных 10-ти образцов заполнителей пирокластических потоков (см. рис. 4б). Также среди заполнителей потоков образцы 2 и 3 имеют наименьшие значения медианы и среднего размера (рис. 5а), обладают наилучшей сортированностью отложений (см. рис. 5б). На основании вышеуказанных особенностей образцов пирокластики вполне логично разделить их на два типа пирокластических потоков.

Частицы заполнителя отложений потоков были представлены обломками лавы и обломками и сростками минералов: плагиоклаза, пироксена, роговой обманки, магнетита. Пепел облаков потоков на $\sim 70 \%$ состоял из обломков вулканического стекла и плагиоклаза, на 30\% - из темноцветных минералов.

В соответствии с Петрографическим кодексом России [2008], все изученные породы, разделенные, соответственно, на пеплы облаков потоков и два типа пирокластических потоков, относятся к нормально-щелочным, пеплы облаков потоков классифицированы как плагиодациты, заполнители пирокластических потоков - как андезиты (таблица).

\section{ОБСУЖДЕНИЕ МАТЕРИАЛА}

До августа 2005 г. вулканологи располагали только наземными данными, которые показали, что видимая высота лавового купола в результате извержения уменьшилась на 130 м [Гирина и др., 2006]. Характерно, что следов гравитационного обрушения какого-либо сектора лавового купола не наблюдалось, кромка купола везде сохранилась достаточно высокой, лишь в его юго-юго-западной части отмечалась небольшая ложбина. При активном внедрении свежей лавы к началу апреля западная и восточная части купола почти сравнялись по высоте [Гирина и др., 2006].

Проведенная в августе 2005 г. аэрофотосъемка купола Молодого Шивелуча (рис. 6а) [Ramsey et al., 2012] позволила лучше понять процесс подготовки и характер эксплозивного извержения, произошедшего 22 сентября 2005 г.

Анализ фотоснимков вулкана Молодой Шивелуч (см. рис. 6б) приводит к выводу, что во время февральского пароксизма 2005 г. в западной части лавового купола образовался эксплозивный кратер диаметром около 600 м. Именно этим обу- 

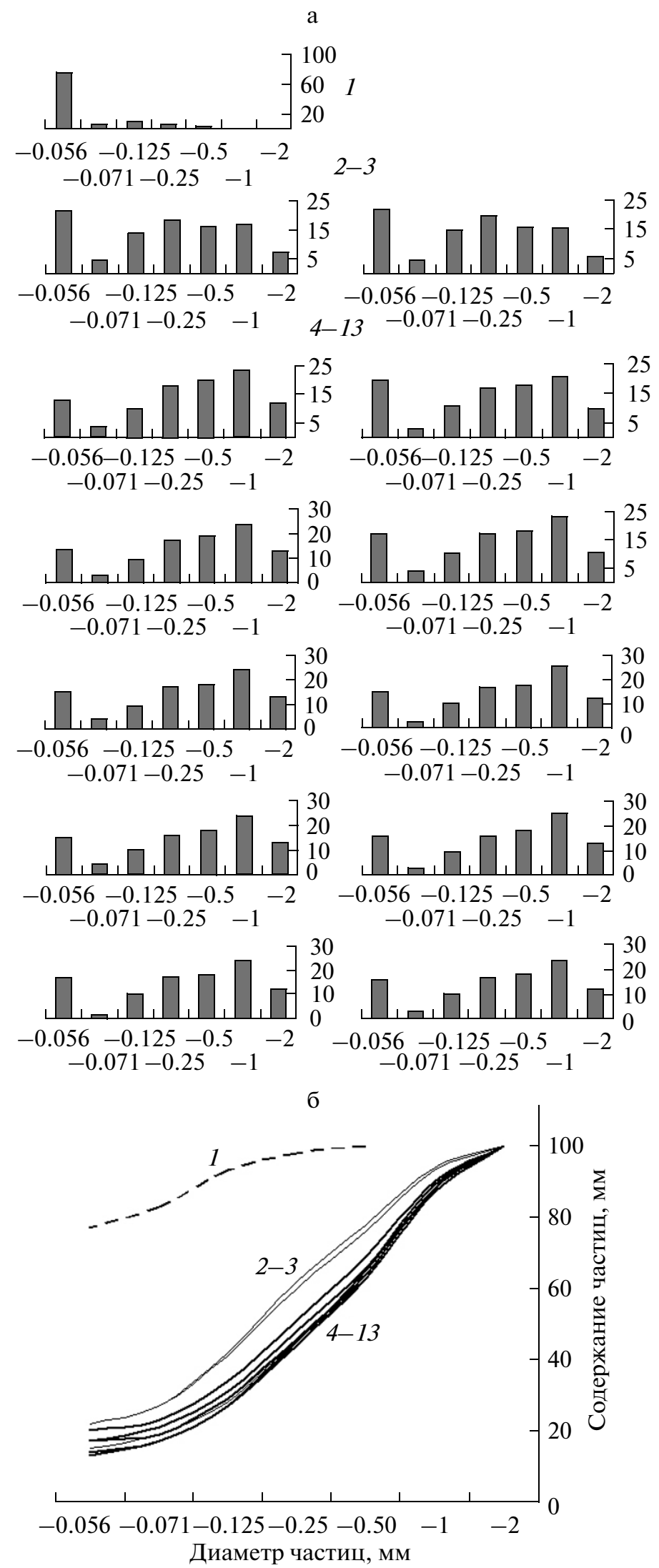

Рис. 4. Диаграммы (а) и кумулятивные кривые (б) гранулометрического состава пирокластических отложений извержения 22 сентября 2005 г.: 1 - пеплов облаков потоков; 2-3 - заполнителей пирокластических потоков 1-го типа; 410 - заполнителей пирокластических потоков 2-го типа. 

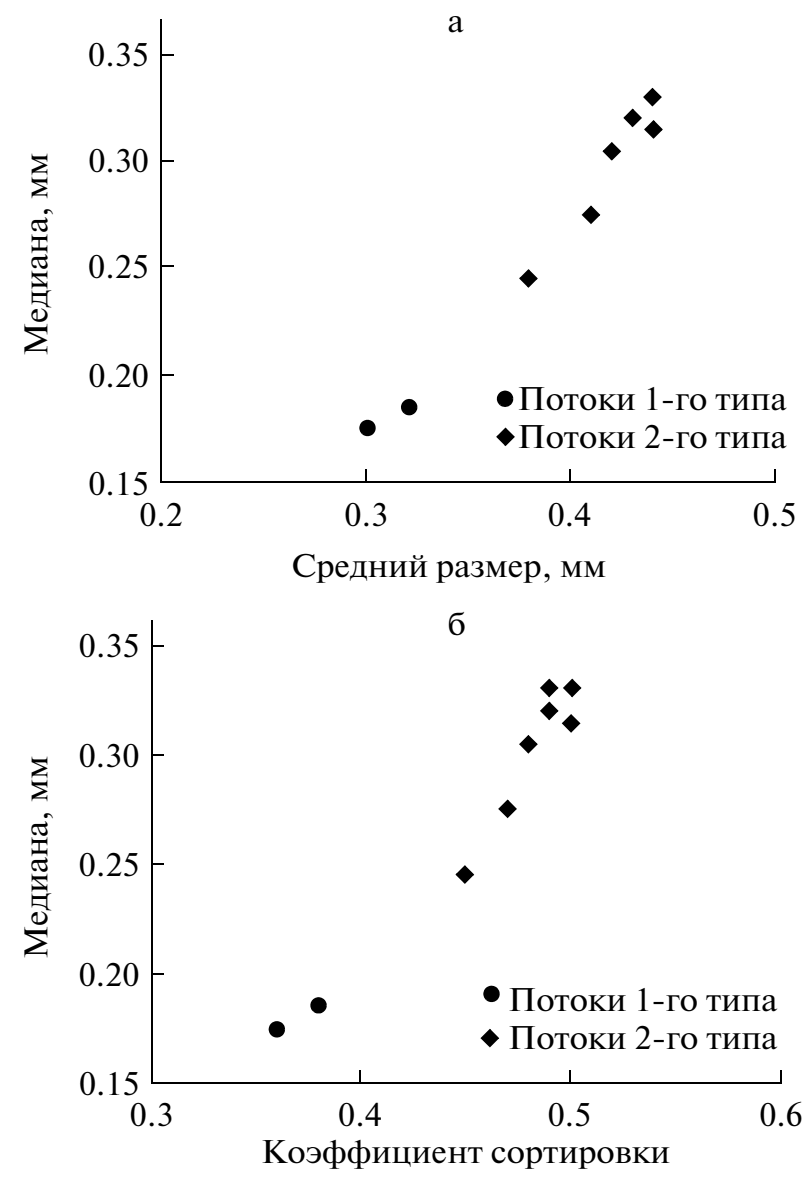

Рис. 5. Соотношения гранулометрических характеристик частиц заполнителей пирокластических отложений извержения 22 сентября 2005 г.: медианы и среднего размера (а) и медианы и коэффициента сортировки (б).

словлен такой огромный объем продуктов, изверженных 27 февраля 2005 г. (протяженность пирокластических потоков до 25-28 км от кратера вулкана, общий объем продуктов - около $0.5 \mathrm{kM}^{3}$ [Нуждаев и др., 2005; Гирина и др., 2006]). Сразу после февральского пароксизма началось активное, но спокойное (не сопровождавшееся эксплозиями), выжимание пластичной лавы в кратер, продолжавшееся, вероятно, в течение трех месяцев (март-май), пока кратер не заполнился экструзивным материалом. Диаметр короны нового лавового купола (5 на рис. 6б), выросшего в кратере, на 20 августа 2005 г. составлял примерно 400-450 м [Ramsey et al., 2012]. В июне-июле эксплозивные события наблюдались в районе лавового купола достаточно часто, возможно, 29-30 июня во время интенсивной эксплозивной активности вулкана в центре нового купола, образовавшегося в марте-июне, появился новый эксплозивный кратер, заполнившийся затем свежими порциями пластичной лавы. Диаметр короны новейшего лавового купола составил около 300 м (6 на рис. 6б)
[Ramsey et al., 2012]. На высокую пластичность выжимавшейся лавы и относительно быстрое поступление ее на поверхность земли указывают длинные изогнутые ленты лавы, выжимавшиеся по трещине на вершине новейшего купола (7 на рис. 6б). В течение июня-сентября продолжалось выжимание блоков пластичной лавы, иногда наблюдались короткие лавовые потоки. Очередная сильная эксплозия 22 сентября спровоцировала, с одной стороны, обрушение части юго-западного сектора лавового купола, с другой стороны, быстрый вынос ювенильного вещества, что привело к формированию высокоподвижных пирокластических потоков пористых андезитов.

Пирокластические потоки извержения 22 сентября 2005 г. формировались из лавового материала купола, образовавшегося в течение мартасентября 2005 г., ювенильного вещества, вынесенного из недр вулкана в течение эксплозивной фазы извержения, а также частично из пород купола, сформировавшихся в 2001-2004 гг. и ранее. Высокая мобильность пирокластических потоков, протянувшихся на 20 км от вулкана, обусловлена несколькими причинами: составом пород андезиты, дациандезиты; высокой газонасыщенностью свежего лавового материала и ювенильной пирокластики, автоэксплозивностью обломков, движущихся в потоке, конвективной гравитационной дифференциацией пирокластики в течение движения по склону вулкана [Гирина, 1998; Гирина, 2010]. В связи с тем, что формирование пирокластических потоков происходит не одновременно [Макдональд, 1975; Алидибиров и др., 1988; Гирина, 1990; Гирина и др., 2006], а в течение относительно длительного времени (в данном случае, в течение 8.6 ч), порции потоков постоянно смешивались; но грубообломочные потоки, если таковые и были во время этого извержения, в любом случае были погребены под более мобильными средне- и мелкозернистыми потоками пирокластики, и не могли нами рассматриваться спустя 12 дней после извержения (в связи с высокой температурой отложений, лежащих на поверхности земли).

Два типа пирокластических потоков, выделенных при детальном изучении пирокластики, связаны, вероятно, со сложным процессом их образования. Хотя по химическому составу потоки двух типов достаточно близки, гранулометрические характеристики их различны. Вероятно, потоки 2-го типа (10 образцов заполнителей пирокластических потоков) в большей мере состоят из материала продуктов разрушения свежих блоков лавового купола, образовавшихся в течение марта-сентября 2005 г., и в меньшей мере - из ювенильной пирокластики, вынесенной во время эксплозивного извержения вулкана 22 сентября. Отложения пирокластического потока 1-го типа (2 образца пород) как наиболее мобильные (газо- 

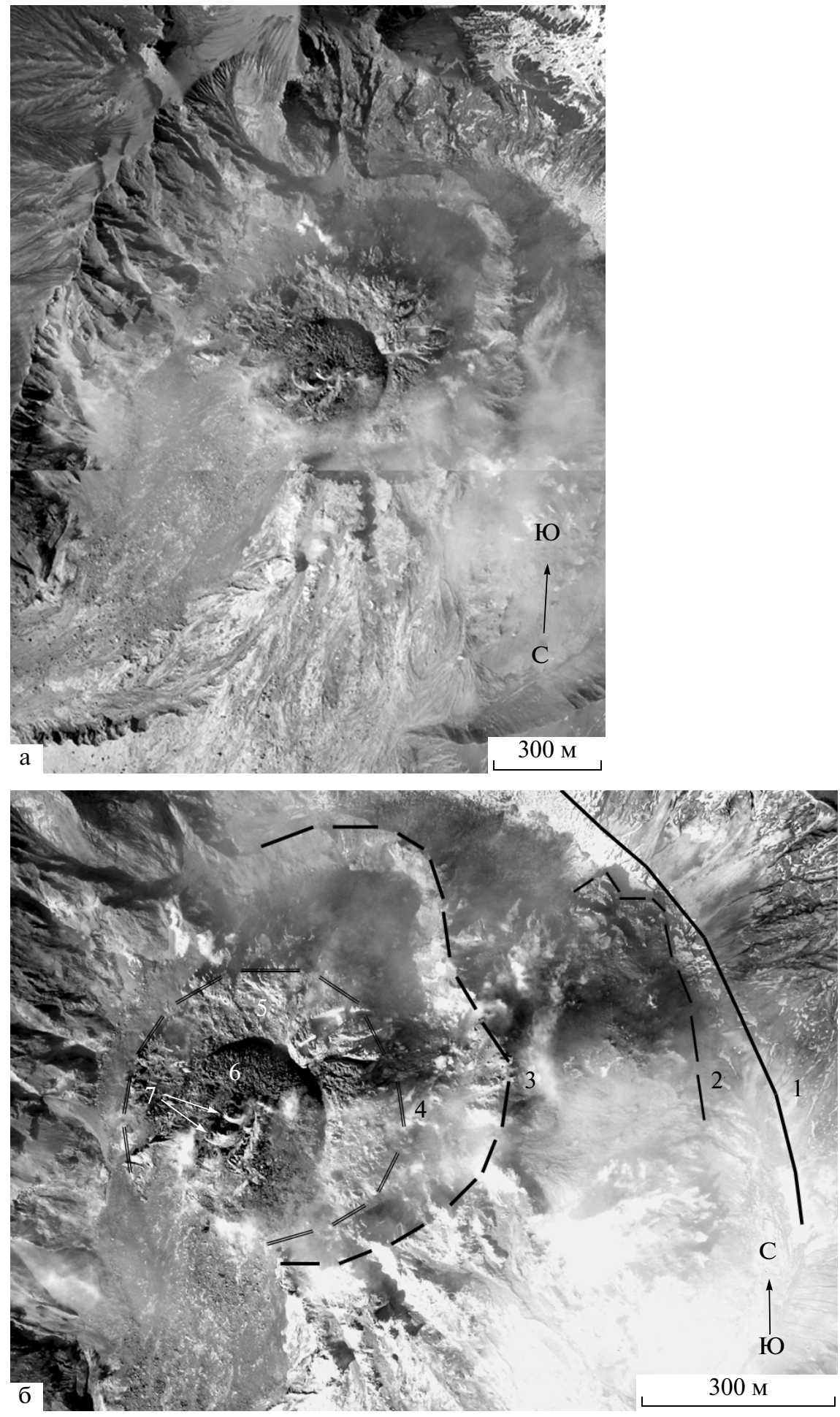

Рис. 6. Лавовый купол вулкана Молодой Шивелуч 20 августа 2005 г., фото M. Ramsey: общий вид (а); структуры вулкана (б).

1 - край эксплозивной воронки, образовавшейся при катастрофическом извержении в 1964 г; 2 - подножие современного лавового купола по состоянию на 2005 г.; 3 - эксплозивная воронка, образовавшаяся при извержении 27 февраля 2005 г.; 4 - корона нового лавового купола (5), сформированного в этой воронке в марте-августе 2005 г.; 6 - новейший лавовый купол внутри нового; 7 - пластичные ленты лавы, выжатые по трещине на вершине новейшего купола. 
Химический состав (в мас. \%) пирокластических пород вулкана Шивелуч, изверженных 22 сентября 2005 г.

\begin{tabular}{|c|c|c|c|c|c|c|c|c|c|c|c|c|c|}
\hline \multirow{2}{*}{$\begin{array}{l}\text { Номер } \\
\text { образца }\end{array}$} & \multirow{2}{*}{$\begin{array}{c}\text { Пепел } \\
1\end{array}$} & \multicolumn{2}{|c|}{$\begin{array}{c}\text { Пирокластические } \\
\text { потоки 1-го типа }\end{array}$} & \multicolumn{10}{|c|}{ Пирокластические потоки 2-го типа } \\
\hline & & 2 & 3 & 4 & 5 & 6 & 7 & 8 & 9 & 10 & 11 & 12 & 13 \\
\hline $\mathrm{SiO}_{2}$ & 67.36 & 62.42 & 62.89 & 62.57 & 63.13 & 62.44 & 62.54 & 62.53 & 62.55 & 62.58 & 62.18 & 62.29 & 62.09 \\
\hline $\mathrm{Al}_{2} \mathrm{O}_{3}$ & 15.03 & 16.27 & 16.41 & 16.03 & 16.31 & 16.09 & 16.03 & 16.08 & 16.17 & 16.07 & 16.12 & 16.05 & 16.08 \\
\hline $\mathrm{Fe}_{2} \mathrm{O}_{3}$ & 1.47 & 2.18 & 2 & 2.28 & 2.11 & 2.15 & 2.08 & 2 & 1.98 & 2.21 & 2.07 & 2.19 & 1.97 \\
\hline $\mathrm{FeO}$ & 1.58 & 2.15 & 2.01 & 2.01 & 1.94 & 2.01 & 2.15 & 2.15 & 2.08 & 2.01 & 2.15 & 2.15 & 2.37 \\
\hline $\mathrm{CaO}$ & 4.47 & 6.13 & 5.97 & 6.25 & 5.97 & 6.1 & 6.18 & 6.12 & 6.05 & 6.12 & 6.2 & 6.36 & 6.27 \\
\hline $\mathrm{MgO}$ & 2.48 & 3.69 & 3.51 & 3.82 & 3.59 & 4.08 & 3.9 & 3.93 & 4.03 & 3.87 & 4.14 & 3.89 & 4.02 \\
\hline $\mathrm{Na}_{2} \mathrm{O}$ & 4.68 & 4.29 & 4.43 & 4.34 & 4.45 & 4.47 & 4.39 & 4.43 & 4.51 & 4.42 & 4.44 & 4.32 & 4.35 \\
\hline $\mathrm{TiO}_{2}$ & 0.434 & 0.536 & 0.506 & 0.533 & 0.509 & 0.519 & 0.529 & 0.52 & 0.513 & 0.521 & 0.528 & 0.543 & 0.539 \\
\hline $\mathrm{K}_{2} \mathrm{O}$ & 1.55 & 1.33 & 1.33 & 1.27 & 1.29 & 1.23 & 1.26 & 1.25 & 1.23 & 1.24 & 1.23 & 1.26 & 1.22 \\
\hline $\mathrm{MnO}$ & 0.059 & 0.086 & 0.079 & 0.086 & 0.081 & 0.081 & 0.084 & 0.081 & 0.08 & 0.083 & 0.083 & 0.087 & 0.087 \\
\hline $\mathrm{P}_{2} \mathrm{O}_{5}$ & 0.15 & 0.151 & 0.149 & 0.151 & 0.145 & 0.15 & 0.147 & 0.15 & 0.149 & 0.147 & 0.15 & 0.149 & 0.15 \\
\hline Ппп & 0.58 & 0.58 & 0.56 & 0.5 & 0.3 & 0.52 & 0.054 & 0.6 & 0.5 & 0.56 & 0.56 & 0.54 & 0.68 \\
\hline Сумма & 99.84 & 99.813 & 99.844 & 99.84 & 99.825 & 99.84 & 99.83 & 99.841 & 99.842 & 99.831 & 99.851 & 99.829 & 99.826 \\
\hline
\end{tabular}

Примечание. Анализы пород выполнены в Аналитическом центре ИВиС ДВО РАН. Проба пепла (1) предоставлена С.Л. Сенюковым (КФ ГС РАН). 
насыщенные), тонкозернистые, вероятно, наоборот, сложены большей частью ювенильным материалом и меньшей - продуктами разрушения блоков лавового купола, образовавшихся в течение марта-сентября 2005 г.

Авторы приносят благодарность Ю. Демянчуку и M. Ramsey за предоставленные фотографии.

\section{СПИСОК ЛИТЕРАТУРЫ}

Алидибиров М.А., Богоявленская Г.Е., Кирсанов И.Т. и др. Извержение вулкана Безымянный в 1985 г. // Вулканология и сейсмология. 1988. № 6. С. 3-17.

Богоявленская Г.Е., Брайцева О.А. О генетической классификации пирокластических отложений и типах отложений вулкана Безымянный в 1955-1956 гг. // Вулканология и сейсмология. 1988. № 3. С. 39-55.

Гирина O.A. Пирокластические отложения современных извержений андезитовых вулканов Камчатки и их инженерно-геологические особенности. Владивосток: Дальнаука, 1998. 174 с.

Гирина O.A. Современная активность вулкана Молодой Шивелуч // Всероссийская научная конференция “100-летие Первой Камчатской экспедиции Русского географического общества 1908-1910 гг.” 21-28 сентября 2008 г., Петропавловск-Камчатский.

http://www.kscnet.ru/ivs/slsecret/konf_r/kam_100/pages/IMG_1681+555.htm

Гирина О.А. Конвективная гравитационная дифференциация пирокластики андезитовых вулканов // Литосфера. 2010. № 3. С. 135-144.

Гирина О.А. Пирокластические отложения извержения вулкана Безымянный в октябре 1984 г. // Вулканология и сейсмология. 1990. № 3. С. 82-91.

Гирина О.А., Демянчук Ю.В., Мельников Д.В. и др. Пароксизмальная фаза извержения вулкана Молодой Шивелуч, Камчатка, 27 февраля 2005 г. (предварительное сообщение) // Вулканология и сейсмология. 2006. № 1. C. 16-23.

Гирина О.А., Маневич А.Г., Малик Н.А. и др. Действующие вулканы Камчатки и Северных Курил в 2005 г. // Вулканология и сейсмология. 2007a. № 4. С. 29-40.

Гирина О.А., Ушаков С.В., Демянчук Ю.В. Пароксизмальное извержение вулкана Молодой Шивелуч, Камчатка, 9 мая 2004 г. // Вестник КРАУНЦ. Науки о Земле. 2007б. № 2. Вып. 10. С. 65-73.

Горбач Н.В. Формирование экструзивного купола вулкана Шивелуч и состав его лав в 2004-2005 гг. // Проблемы эксплозивного вулканизма (к 50-летию катастрофического извержения вулкана Безымянный). Материалы Первого международного симпозиума, 25-30 марта 2006 г., Петропавловск-Камчатский. Петропавловск-Камчатский: ИВиС ДВО РАН, 2006. C. $112-119$.

Двигало В.Н. Рост купола кратера вулкана Шивелуч в 1980-1981 гг. по фотограмметрическим данным // Вулканология и сейсмология. 1984. № 2. С. 105-108.

Жаринов Н.А., Богоявленская Г.Е., Хубуная С.А., Демянчук Ю.В. Новый эруптивный цикл вулкана Шивелуч 1980-1993 гг. // Вулканология и сейсмология. 1995. № 1. C. $20-28$.
Макдональд Г. Вулканы. М.: Мир, 1975. 432 с.

Мелекесцев И.В., Волынеи О.Н., Ермаков В.А. и др. Вулкан Шивелуч // Действующие вулканы Камчатки. М.: Наука, 1991. С. 84-92.

Нуждаев А.А., Гирина О.А., Мельников Д.В. Некоторые результаты изучения пирокластических отложений извержений 28 февраля и 22 сентября 2005 г. вулкана Молодой Шивелуч наземными и дистанционными методами // Вестник КРАУНЦ. Науки о земле. 2005. № 2. Вып. 6. С. 62-66.

Петрографический кодекс России. Магматические, метаморфические, метасоматические, импактные образования. Издание второе, переработанное и дополненное. СПб.: Изд-во ВСЕГЕИ, 2008. 200 с.

Пополитов Э.И., Волынеи О.Н. Геохимические особенности вулканических пород Курило-Камчатской островной дуги и некоторые вопросы петрогенезиса. Новосибирск: Наука, 1981. 182 с.

Рудич К.Н., Волынеи О.Н., Ермаков В.А., Колосков А.В. Многообразие вулканических пород Камчатки и проблемы их генезиса // Геодинамика, магмообразование и вулканизм. Петропавловск-Камчатский. 1974. C. 235-249.

Сенюков С.Л., Дрознина С.Я., Нуждина И.Н. и др. Исследования вулканов Камчатки дистанционными методами в 2005 г. // Проблемы эксплозивного вулканизма (к 50-летию катастрофического извержения вулкана Безымянный). Материалы Первого международного симпозиума, 25-30 марта 2006 г., Петропавловск-Камчатский. Петропавловск-Камчатский: ИВиС ДВО РАН, 2006. С. 64-75.

Серафимова E.К. Минеральные парагенезисы вулканических возгонов // Постэруптивное минералообразование на активных вулканах Камчатки. Материалы Первой сессии Камчатского отделения ВМО, Петропавловск-Камчатский, 1989 г. Владивосток: ДВО АН СССР, 1992. Часть 1. С. 31-52.

Федотов С.А., Двигало В.Н., Жаринов Н.А. и др. Извержение вулкана Шивелуч в мае-июле 2001 г. // Вулканология и сейсмология. 2001. № 6. С. 3-15.

Федотов С.А., Иванов Б.В., Двигало В.Н. и др. Деятельность вулканов Камчатки и Курильских островов в 1984 г. // Вулканология и сейсмология. 1985. № 5. C. $3-23$.

Хубуная С.А., Жаринов Н.А., Муравьев Я.Д. и др. Извержение вулкана Шивелуч в 1993 г. // Вулканология и сейсмология. 1995. № 1. С. 3-19.

Girina O.A., Chubarova O.S., Senyukov S.L. The Recent Activity of Sheveluch Volcano // Abstracts. $3^{\text {rd }}$ Biennial Workshop on Subduction Processes emphasizing the KurileKamchatka-Aleutian Arcs. Fairbanks. 2002. P. 121-122.

Ramsey M.S., Wessels R.L., Anderson S.W. Surface textures and dynamics of the 2005 lava dome at Shiveluch volcano, Kamchatka // GSA Bulletin. May/June 2012. V. 124. № 5/6. P. 678-689. doi: 10.1130/B30580.1. 


\section{ON SOME FEATURES PECULIAR TO THE SEPTEMBER 22, 2005 ERUPTION OF YOUNG SHIVELUCH VOLCANO, KAMCHATKA}

\section{O. A. Girina and A. A. Nuzhdaev}

Institute of Volcanology and Seismology, Far East Branch, Russian Academy of Sciences,

Petropavlovsk-Kamchatskii, 683006 Russia

e-mail: girina@kscnet.ru

Received June 17, 2013

Abstract-An explosive eruption of Young Shiveluch Volcano occurred on September 22, 2005, discharging a pyroclastic flow about $20 \mathrm{~km}$ long in the Baidarnaya River valley and an ashfall in the area of the Northern cluster of volcanoes. 